\title{
GENDER VERSUS MARITAL CONCERNS \\ DOES 1 CORINTHIANS 11:2-16 ADDRESS THE ISSUES OF \\ MALE/FEMALE OR HUSBAND/WIFE?
}

Preston T. Massey

\begin{abstract}
Summary
This study proposes an alternative for interpreting the background to 1 Corinthians 11-14. The investigation will focus on the following three issues: 1) the issue of married women versus any woman; 2) the matter of a married woman's talking in a public setting; and 3) the nature of the church as the family of God meeting in a house for public worship. The combination of these factors will lead to the conclusion that Paul is addressing marital issues.
\end{abstract}

\section{Introduction}

In a long and distinguished career devoted to Pauline studies, Jerome Murphy-O'Connor has established a significant publication record on issues related particularly to 1 Corinthians. Of special interest has been his focus on clarifying the nature of the problem as addressed in the pericope of 1 Corinthians 11:2-16. Murphy-O'Connor has developed arguments that Paul was combating the blurring of the sexes through the styling of male and female hairdos: by wearing long hair the men were flirting with notions of homosexuality; the women by wearing short hair were at risk of appearing mannish. Murphy-O'Connor has been relentless in pursuing this thesis. ${ }^{1}$ The Murphy-O'Connor

1 See, for example, J. Murphy-O'Connor, 'Eucharist and Community in First Corinthians', Worship 50 (1976): 370-85, reprinted in 'House Churches and the Eucharist', originally published in The Bible Today 22.1 (1984); and reprinted in St. Paul's Church: Texts and Archaeology (Collegeville: Liturgical Press, 2002): 178-85; and reprinted again in Keys to First Corinthians: Revisiting the Major Issues (Oxford: Oxford University, 2009): 194-229, esp. 195: 'Paul's concern is that the difference between men and women should be proclaimed by their modes of dress. His motive for 
proposal has not been ignored. Numerous scholars have taken on the case he presents: some have challenged his thesis; others have come to his aid. ${ }^{2}$

\section{Married Men and Women or any Man or Woman?}

There is no consensus on who Paul is precisely addressing in 1 Corinthians 11:2-16 and 14:34-35. Is he addressing men and women in general, ${ }^{3}$ or husbands and wives in particular? ${ }^{4}$ Regarding 1 Corinthians 11:2-16 there is the additional problem of whether both sexes are addressed or just one. The recent commentary by Roy E. Ciampa and Brian S. Rosner presents the dilemma facing scholars: 'The decisions are difficult ones, and no real consensus has been reached. It may be that Paul's approach reflects more than one of the concerns highlighted by various interpreters. ${ }^{5}$ It appears that the evidence follows two separate paths: either Paul is addressing gender issues of male and female distinctions or he is concerned about marital implications. If the problem is one of gender, the issues swing on hair styles and a lifestyle outside the church as well as inside. If the problem is safeguarding marriages, the issues are likely ones concerning veiling and a particular behaviour while at church. In whatever manner one

asserting this obvious point is never brought to light, but there is some justification for the hypothesis that his secret fear was an outbreak of homosexuality and/or lesbianism.'

2 Raymond F. Collins, First Corinthians (Collegeville: Liturgical Press, 1999): 399, after citing a litany of ancient authors, says: 'That men should be men and women should be women, and should look like what they are, is something important to all authors. Their fear is homosexuality and pederasty.' See also his conclusion (407): 'Some commentators, however, conjecture that the reference to the head goes back to v. 3 and that it is the woman's husband whom she has disgraced by wearing her hair down ... Were this the correct interpretation Paul would have been strongly urging the subordination of Christian wives to their husbands.'

3 For the argument that matrimonial concerns are not in view, see Jorunn Økland, Women in Their Place: Paul and the Corinthian Discourse of Gender and Sanctuary Space (London: T\&T Clark, 2004): 217. For the argument that no gender distinctions are in view, see Richard B. Hays, First Corinthians (Louisville: John Knox, 1997): 185.

4 For the view that Paul is, in fact, addressing marital issues, see David E. Garland, 1 Corinthians (Grand Rapids: Baker Academic, 2003): 667-68.

5 R. E. Ciampa and B. S. Rosner, The First Letter to the Corinthians (Grand Rapids: Eerdmans, 2010): 512. See also Anthony Thiselton, The First Epistle to the Corinthians: A Commentary on the Greek Text (Grand Rapids: Eerdmans, 2000): 825, for similar ambivalence. 
cuts the cake, it does not seem likely that Paul is addressing both at the same time. In any case, the interpretative path that we will pursue in this paper is that it is more logical to argue for one interpretation rather than both.

\section{The Issue of Gender or the Marriage Relationship}

What can be said to adjudicate the issue? We begin with the terms most capable of identifying the specific issue: ruví and ávíp. The noun ruví is used sixteen times in this text and its companion óvíp fourteen. Clearly they are the subject of 1 Corinthians 11:2-16. ruví itself is used in the NT over ninety times. Of this number, I count seventy references as describing a wife. Luke 20:33 is a case in which ruví is used of both wife and woman. Therefore, the word can be a general and comprehensive term to include all women, or it can have a particular usage confined only to the meaning 'wife'. In fact, ancient Greek does not have a separate word for 'woman'. Words exist for virgin, female, wife, mother, grandmother, and widow but not for woman. The individual word ruví thus performs a double function serving as the noun for both woman and wife. Therefore, a text containing both $\gamma u v \eta ́$ and óvíp may describe either man and woman or husband and wife. This also applies to the generic word óv $\theta \rho \omega \pi \% \varsigma$ which can be found in the feminine. ${ }^{6}$ Since the word ruví possesses this twofold ability, the question then becomes: which of the two definitions best applies to the text? The key to answering this question and for threading this interpretative needle is the context. ${ }^{7}$ We begin with an admission: it is impossible to impose throughout the pericope a single meaning for the óvíp/ruví pair as used in 1 Corinthians 11:216. For example, the meaning of 'husband/wife' cannot be squeezed into the language of verse 12 . In verse 12 the meaning cannot be that a husband comes from a wife but, more appropriately, a man from a woman. Likewise, the 'man/woman' binary does not fit well in verse 5

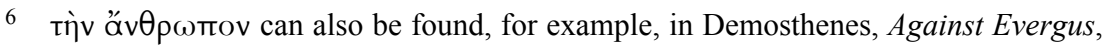
47.

7 The Imperial writer Plutarch provides a clue in his Apophthegmata laconica (232C) in which he uses the óvíp / Yuví pair for husband and wife; yet in his essay Mulierum virtutes $(242 \mathrm{~F})$ he clearly uses this pair as man and woman. The particular context of a given pair must determine the outcome. 
because it is not likely that any woman in general can shame any man in general.

How then can we adjudicate the issue? What can help to tip the scales to one side or the other? I suggest that the language of 'man/woman' be placed in the service of understanding that the key point and main application of this pericope is directed at clarifying the husband/wife relationship while in a public setting. The upshot of this logic would be that the meaning of verse 5 does not bring balance to verse 12 , but that verse 12 helps to explicate and bring balance to verse 5. This line of logic would, therefore, make verse 12 subordinate to verse 5 , not the other way around. In my judgement, verse 5 is not describing any woman in general (whether single, married, divorced, or widowed) but married women only. The singular reference in verse 5

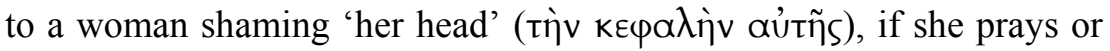
prophesies with an uncovered head, makes suitable sense if the definite article tìv limits the application to her own head, that is metaphorically her husband. Taken in this sense, the text is not telling unmarried women that if they pray with head uncovered, they will shame men but, rather, a married woman will shame her own husband if she prays or prophesies with head uncovered.

A helpful guide on this matter is to refer back to 1 Corinthians $7: 1$ -

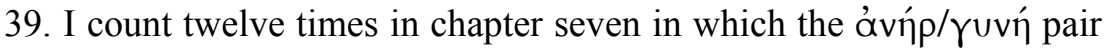
are used to describe the husband/wife relationship. The first verse is

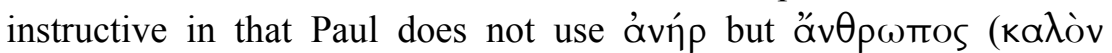

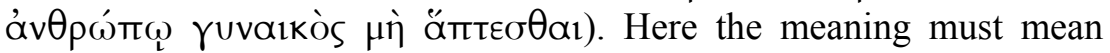
that 'it is well for an unmarried man not to touch a woman'. (It would make little sense to interpret this as meaning that it is well for a married man not to touch his wife.) What follows next are several injunctions that can apply only to married men and women. All examples employ

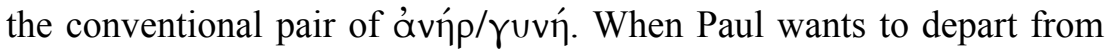
addressing married couples, he indicates so by means of a specific

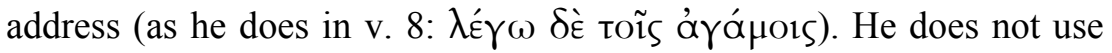
the óví $\rho / \gamma u v \eta ́$ couplet in this section. When he desires to return to further address those who are married, he then identifies the addressees as he does in verse 10 (тoĩ $\delta \dot{\varepsilon} \gamma \varepsilon \gamma \alpha \mu \eta$ Kóoıv) and, accordingly, in this section there are two more examples of the óví $\rho / \gamma u v \eta ́$ pair. This entire

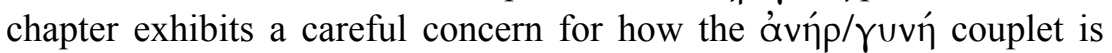
used, and this couplet is not used to describe the unmarried. 


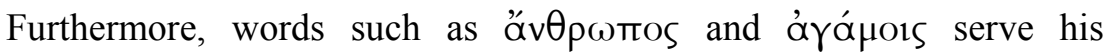
purpose when addressing the unmarried.

When we turn to 1 Corinthians 11:2-16, this breakdown by marital status is missing. What can we conclude from this silence? One way of cutting the cake is to decide that if no marital status is given, then none is implied. The other way is to argue the opposite: since the unmarried are not mentioned, then none are implied. Although there are exceptions, the compendium of references suggests a consistency for understanding this pair of words as referring to a husband and wife.

Similarly, the reference in 1 Corinthians 14:35 enjoining the women to ask '́v oík translated as, 'ask their own husbands at home'. If so, the question then becomes: does this translation make the best sense? To answer this question and further support the view that it is wives under consideration and not women in general, the language of 1 Corinthians

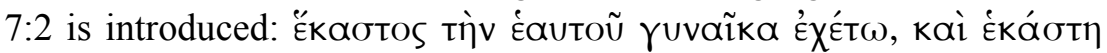

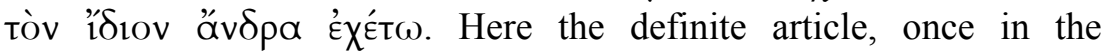
masculine and once in the feminine, clearly identifies that the subject and object refer to husbands and wives in particular, not to men and women in general. That is not all. For additional emphasis the text includes the adjective ' $1 \delta$ tos which stresses 'one's own' in contrast to something that is public or general in nature. ${ }^{8}$ Texts from Josephus may illustrate the point. For example, Josephus consistently contrasts something that is private, personal, and belonging to an individual by using the adjective $i^{\delta} \delta$ os to clarify his argument. However, when he wants to describe something that is common, non-personal, and of general use, he employs such terms as kolvós ('common'), ${ }^{9} \delta \eta \mu o \sigma i ́ a$ ('public'), ${ }^{10}$ or a form of ${ }^{\prime} \lambda \lambda_{0}$ - ('another'). ${ }^{11}$ Of particular interest is his use of ' $1 \delta$ ios with the word ruví. In three of the four texts where this combination is found, the translation which best fits the context is 'his own wife'. ${ }^{12}$

To further underscore the point, there is another pair of words:

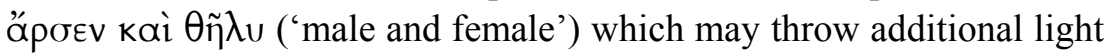
upon the issue. If, in either 1 Corinthians 11:2-16 or 14:34-35, Paul had

8 BDAG 2000: 466.

9 Jewish War 4.226; 7.260; Antiquities 4.310; 5.92; 8.297; $14.151 ; 16.39$.

10 Antiquities $3.251 ; 4.99$.

11 Jewish War 2.85; Antiquities 19.305.

12 Jewish War 1.483; 2.237; Antiquities 8.368. 
wanted to clarify gender issues of maleness and femaleness, he had at his disposal the perfect pair of ápoєv kaì $\theta \tilde{\eta} \lambda u$. However, this is not his pair of choice. Why the omission? Is it because he had already declared equality between male and female in Galatians 3:28 and to introduce this pair into the discussion would only confuse and undermine this principle? Or, is it because the male/female binary is not under discussion? ${ }^{13}$ This omission leads me to believe that, once again, the domestic issues of the husband/wife relationship are in view. If this conclusion is correct, the context of 1 Corinthians 11:2-16 is not

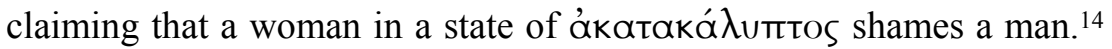
Rather, it is a wife in this condition who shames her husband. ${ }^{15}$ This potentially implies that one of the concerns in the text that Paul is

13 For a completely different reading of these issues in 1 Cor. 11.2-16, see Dale B. Martin, The Corinthian Body (New Haven: Yale University, 1995), esp. his concluding paragraph (248-49) in which he mentions only the issue of gender by the various terms of: 'male-female hierarchy', 'female' $(4 \times)$, 'female nature', 'women's bodies' $(2 \times)$, 'femininity' $(2 \times)$, 'women' $(3 \times)$, and 'female stuff'. He does not consider the domestic issue of the husband/wife relationship.

14 We are thus using 1 Cor. 7 as a contextual guide for understanding 1 Cor. 11:2-16. Strengthening the case for a 'husband/wife' interpretation, is the recent observation by Terence Paige, 'The Social Matrix of Women's Speech at Corinth: The Context and Meaning of the Command to Silence in 1 Corinthians 14:33b-36', BBR 12.2 (2002): 217-42, esp. 224, who has correctly supplied an additional line of evidence for the

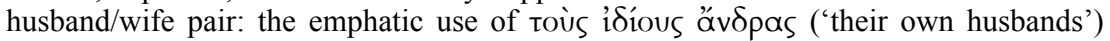
indicates that the text is addressing married women, and the injunction is designed to curb the impulse of married women from talking with non-family males. This implies, among other things, that these married women are not to address a question to a man other than her own husband. The implication being that this would, on one hand, be felt as a slight or putdown by her own husband - thus engendering one kind of shame; and, on the other hand, be perceived as a flirtatious overture on her part - thereby engendering another kind of shame or impropriety. In either case, those in attendance would sense a measure of awkwardness. For the counter-argument that ruví is a generic term including even virgins, see Geoffrey D. Dunn, 'Rhetoric and Tertullian's De Virginibus Velandis', VC 59 (2005): 1-30, esp. 16.

15 Regarding the language of husband and wife, Økland makes a claim that cannot be substantiated (Women in Their Place, 14): 'Nor is ruví a semantically equivalent term to ávíp, "man", in ancient Greek usage. I am thinking here of the fact that for

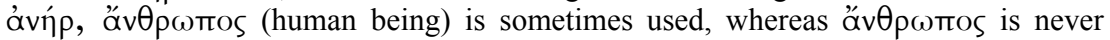
used synonymously with ruví. ruví is often translated "women" but there was no other, separate word for "wife" as there is in English and Norwegian.' Økland's claim is incorrect on two counts. First, there are many other words for 'wife' in Greek.

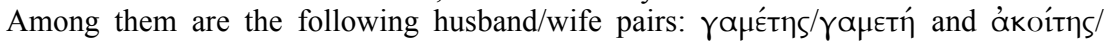

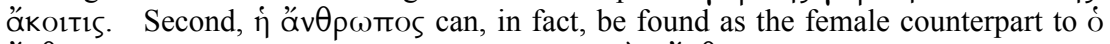

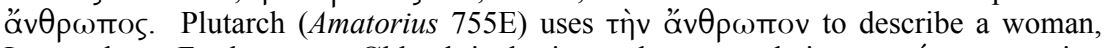
Ismenodora. Furthermore, Økland is hesitant about translating ruví as meaning 'wife'. Although there are exceptions, whenever ruví and ávíp appear together, as they do in 1 Corinthians 11:2-16, convention generally suggests that this pair be understood as husband and wife. 
trying to protect is the husband-wife relationship. Paul would then be enjoining married women to appear in public with the appropriate headdress for the sake of their marriage.

\section{The Issue of House Churches}

Another issue now needs attention. Is it possible that the background to the text of 1 Corinthians 11:2-16 has nothing to do with public worship at all? Commentaries assume the word 'public' in their treatment of this text. ${ }^{16}$ If this public assumption is justified, does it automatically assume that outsiders are present, thus making legitimate the claim for a public worship environment? The activity of prayer and prophecy as described in 1 Corinthians 11:4-5 would suggest that worship of a public nature is the setting. Additionally, there are several references in the overall context of chapters 11-14 which describe the church as an assembled body of people. ${ }^{17}$ It is the fact of their coming together that has brought certain behaviour out in the open. Finally, the $i \delta i \tilde{\omega} \tau \alpha 1$ (outsiders) as mentioned in 1 Corinthians 14:23 are pictured as potentially entering as visitors while the entire congregation is meeting together. In other words, a private meeting closed to outsiders is not likely under consideration. ${ }^{18}$

A further point may be introduced. Augmenting the house church premise as a model for understanding the concerns behind 1 Corinthians 11:2-16 is the current archaeological evidence from

16 For example, Anthony C. Thiselton (The First Epistle to the Corinthians, 825) states: "This section (11.2-16) should not be given the title "The Veiling of Women in Public Worship" (Robertson and Plummer) ... but some such title as "The Subtext behind Issues of Gender Identity and Head Coverings in Public Worship" or "Mutuality and Reciprocity: Self Respect, Respect for the Other, and Gender Identity in Public Worship". In all three of these subtitle options, two of which Thiselton is willing to accept, he retains the wording of 'Public Worship'. Thiselton further amplifies the theme of public worship by extracting the basic principle of 'that which distracts attention from God or Christ in public worship' (italics his, 827-28).

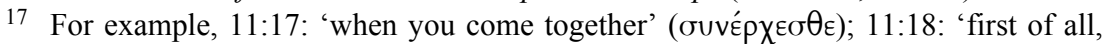

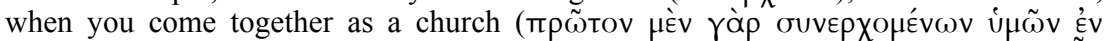

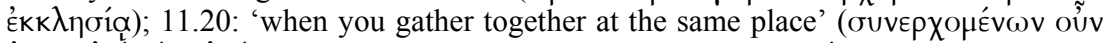

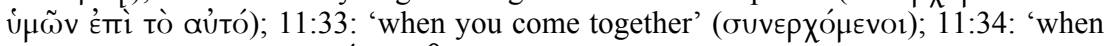

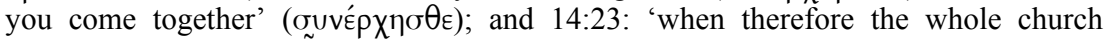

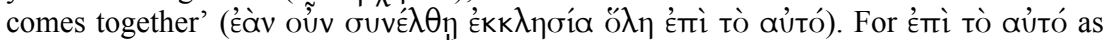
meaning 'at the same place, together', see BDAG 153.3b.

18 David L. Balch, Roman Domestic Art and Early House Churches (Tübingen: Mohr Siebeck, 2008): 237, commenting upon houses at Corinth and Philippi, says: 'I argued in concert with A. Wallace-Hadrill that these houses were open to uninvited visitors'. 
Rome that shows these private homes did not make use of separate rooms dedicated solely for worship. ${ }^{19}$ In other words, the early church in Rome, and we can only surmise in Corinth as well, conducted worship in the same rooms as used for everyday activities. This blending and blurring of spacial boundaries, I suggest, creates a context for confusion.

Carolyn Osiek and David L. Balch make a very helpful observation about house churches in the First Century by suggesting the archaeological evidence (from the middle or end of the Second Century) for such houses which formerly served for the gathering of public worship went through remodelling to accommodate larger audiences. The effect of this accommodation was to transform the perception of this environment from the personal and private into a more public setting. ${ }^{20}$ Working backward from this observation, we come to a consequence of early Christians meeting in private houses: they would be inclined to associate the environment with behaviour. The purpose of the meeting would, in some of their minds, be subordinate to the familiarity of being in their own homes. Since we have no evidence of the church at Corinth meeting at any venue other than a private house, ${ }^{21}$ house church meeting places must be considered

19 See Peter Lampe, Die stadtrömischen Christen in den ersten beiden Jahrhunderten: Untersuchungen zur Sozialgeschichte (Berlin: J. C. B. Mohr/Paul Siebeck, 1989), ET From Paul to Valentinus: Christians at Rome in the First Two Centuries (Minneapolis: Fortress, 2003): 366-80. I note one of Lampe's conclusions (368): 'In view of the concurrence of archaeological and literary evidence, we may conclude that, in the first two centuries, there were no "house churches" in the sense of specific rooms permanently set aside for worship in secular houses'. For the difficulty of interpreting architectural remains from antiquity, see Susan Walker, 'Women and Housing in Classical Greece: the Archaeological Evidence' in Images of Women in Antiquity, ed. A. Cameron and A. Kuhrt, (London: Routledge, 1993): 81-91.

20 Carolyn Osiek and David L. Balch, Families in the New Testament World: Households and House Churches (Louisville: Westminster/John Knox, 1997): 35. See also See L. Michael White, The Social Origins of Christian Architecture: Texts and Monuments (Valley Forge: Trinity International, 1996): 18, 'As we turn, finally, to the Christian building we should not be surprised to find that it too was a renovated private house'. White does caution the reader (23): 'I am not advocating that we naïvely try to take developments found in a third-century eastern garrison and push them back on earlier periods'.

21 For the evidence of private houses serving as meeting places in Corinth, from both textual and archaeological perspectives, see D. Willy Rordorf, 'Was wissen wir über die christlichen Gottesdiensträume der vorkonstantinischen Zeit?', ZNW 55.1 (1964): 110-28, esp. 111, 'Wohl kann man im allgemeinen sagen: die ersten drei Jahrhunderte sind die Zeit der Hauskirchen. Die Christen versammelten sich für ihre Gottesdienste nicht in eigens dazu errichteten Gebäuden, sondern statteten gewisse Räume in schon bestehenden Häusern für ihre gottesdienstlichen Bedürfnisse aus'. See also Bruce 
as a factor behind the instructions in 1 Corinthians 11:2-16. In fact, the number of references to possible house churches at Corinth is unparalleled in the New Testament. These private homes include, if only potentially (none can be excluded out of hand), the following: Titius Justus, Crispus, Stephanas, Gaius and Erastus, Chloe, Priscilla and Aquila. What is at stake is a respect for general Mediterranean custom. There are long standing issues in ancient Greek culture involving the difficulties posed by the house. ${ }^{22}$ From Paris in the palace and his seduction of Helen in Homeric Epic, through Plato's severe injunction against household religion, ${ }^{23}$ all the way to Plutarch's concerns over protecting the house, ${ }^{24}$ we have a sustained and consistent awareness among Greeks that a man's house is not

Button and Fika J. Van Rensburg, 'The "House Churches" in Corinth', NeoT 37.1 (2003): 1-28, for the argument that wealth was not a requirement for hosting the church in one's house. For the additional argument and full endorsement for house churches rather than public buildings, see Osiek and MacDonald, A Woman's Place: House Churches in Earliest Christianity (Minneapolis: Fortress, 2006): 9, where the authors suggest a variety of options within the rubric of a house-church structure. They also examine the concepts of oikos, oikia, domus, as well as pater-familias, and conclude: 'It seems best to leave open the possibility of a variety of different configurations for house-church meetings, in the earliest years at least'.

22 For a comparison of Roman versus Greek housing architecture and the respective gender distinctions associated with such architecture, see Andrew Wallace-Hadrill, 'Engendering the Roman House' in I CLAVDIA: Women in Ancient Rome, ed. E. E. Kleiner and S. B. Matheson, (New Haven: Yale University Art Gallery, 1996): 104115, esp. 109: 'The Greek symposium may indeed mix men and women, but, in contrast to the Roman convivium, it never mixes men external to the household with the female members of the household.' This information, which is confirmed in the literary record, supports the argument of this study in that the church becomes an extended family allowing men, previously extraneous to the family, to intermingle now with women.

23 For arguments showing how worship in a private house was a potential cause of social anxiety, see Dietrich Wachsmuth, 'Aspekte des antiken Mediterranen Hauskults', Numen 27 (1980): 37-75: 'Wachsmuth's compilation of sources reveals the possibility for tension in a house church setting. Some of Wachsmuth's conclusions are that the Roman house is not an official place for worship: (43) "Das Privathaus istwir sahen es mehrfach - ein locus profanus, kein locus sacer". However, the power of the State to interfere is limited in household worship (48): "die Macht des Staates an der Schwelle des Hauses endete". This situation produces Spannungen or a tension between State and private quarters. Wachsmuth's use of Plato's Leges (909d) indicates the possible equal anxiety felt by Greeks regarding the house as a place of worship (48). Plato indicates his own antipathy toward worship in a private house, believing that there should be a State law forbidding such worship. In the Roman period, Cicero echoes similar views as Plato. In his De legibus (2.19) he argues that only the gods of the State may be reverenced in the setting of a private household.'

24 For example, Plutarch's Quomodo adulator ab amico internoscatur 61D. 
necessarily a safe haven against the threat of shame and potential adultery.

Roger W. Gehring examines the oíkos from several vantage points: an atrium house, a villa, a peristyle house, and the insula (a house with a built-in workshop) which are all possible to document archaeologically. ${ }^{25}$ Gehring argues that the Corinthian congregation would have been in the range of a minimum number down to no fewer than thirty to a maximum number of no larger than ninety members. ${ }^{26}$ The privacy of a house church coupled with its smallness would thereby contribute to the ambience of familiarity. A further observation has been made by Jerome Murphy-O'Connor. Using the villa at Anaploga as a hypothetical working model, he hypothesises a twofold division of upper class versus lower class social distinctions based upon the physical separation of triclinium and atrium. ${ }^{27}$ With a total possible seating arrangement of up to fifty persons, some (the less affluent) would be forced to sit in the outer atrium area. ${ }^{28}$ Although MurphyO'Connor does not develop how this seating arrangement would create an atmosphere for the breakdown of sexual distinctions, ${ }^{29}$ if a doublespace seating accommodation is allowed to stand for the first-century Corinthian church, this would further strengthen the case for a smaller and more intimate environment. Other considerations may have come into play as well.

A question remains: why would these Corinthian women abrogate social order? The answer to this question, as developed in this study, is that the church as presented in the New Testament, is a 'house' of worship and prayer. ${ }^{30}$ As a house of worship it presents a double identity. First, it is a public place to which all are free to come. Second,

25 Roger W. Gehring, Hausgemeinde und Mission (Brunnen: Giessen, 2000), ET House Church and Mission: The Importance of Household Structures in Early Christianity (Peabody: Hendrickson, 2004): 130-42.

26 Gehring, House Church and Mission, 139-41.

27 J. Murphy-O'Connor, Keys to First Corinthians, 182-86, here 184, with a postscript at 186-93. An abstract of this article with minor editorial comment is found in Edward Adams and David G. Horrell, Christianity at Corinth: The Quest for the Pauline Church (Louisville: Westminster John Knox, 2004): 129-38.

28 Murphy-O'Connor, Keys to First Corinthians, 183: 'It would be more realistic, therefore, to think in terms of around fifty persons as a base figure'.

29 Murphy-O'Connor, Keys to First Corinthians, 192: 'Anyway, once the hypothesis of two rooms is accepted, the division between insiders and outsiders remains intact, because one room would inevitably have been more prestigious than the other'.

30 In the text of John 2:16 a place of worship is referred to as an oikos. 
as a house the church crosses over into private space. ${ }^{31}$ Members of the community of faith are actually described as a 'household', ${ }^{32}$ address each other as 'brother and sister', ${ }^{33}$ and are called upon to develop an ambience of family intimacy. ${ }^{34}$ This means that total strangers, ordinarily only encountered cautiously in public space, now occupy private and intimate space together. Both men and women are free to mix together, with the possible exception that seating is according to gender. ${ }^{35}$ This misunderstanding over how to properly interpret the social implications of public worship in the context of private space has created a unique phenomenon in Roman Corinth. The fact remains that the language of that religious community is the language of family. This misapplication of the family metaphor is a prescription for confusion, misunderstanding, or tension. ${ }^{36}$

Stephen C. Barton, pursuing the possibility of an innocent confusion behind the text, identified this social reality as a contributing factor behind the tensions in the Corinthian church: ${ }^{37}$ 'For it appears that the

31 The term 'house church' is appropriate to describe the early Christian movement. 1 Cor. 16:19 mentions that the church in Ephesus met for worship in the house of Aquila and Priscilla. See also Rom. 16:5 and Col. 4:15.

32 Gal. 6:10, Eph. 2:19, and 1 Tim. 3:15. Part of the concern prompting the writing of 1 Timothy is the instruction on how to behave in the 'house of God'. Among other things, this involves treating younger women with purity, like sisters.

331 Cor. 7:15.

341 Tim. 5:2.

35 Erwin Goodenough, Jewish Symbols in the Greco-Roman Period, vol. 2 (New York: Pantheon, 1964): 70, has shown from excavations that Jewish women were separated from men in the synagogue. Josephus (JW 5.204) further confirms this for Jewish people at worship. This, of course, is not conclusive evidence that the same conditions existed in Corinth for a predominantly Gentile church. Kathleen E. Corley, Private Women, Public Meals: Social Conflict in the Synoptic Tradition (Peabody: Hendrickson, 1993): 32, indicates that the archaeological evidence makes it difficult to determine where women, if present, actually sat in public meals. Corley ventures the guess that veiling 'may have been required' at social functions in the Graeco-Roman Empire. See also Sharon Lea Mattila, 'Where Women Sat in Ancient Synagogues' in Voluntary Associations in the Graeco-Roman World, ed. J. S. Kloppenborg and S. G. Wilson (New York: Routledge): 266-86.

36 For arguments and details of the floor plans of private houses, see David Balch, 'Rich Pompeiian Houses, Shops for Rent, and the Huge Apartment Building in Herculaneum as Typical Spaces for Pauline House Churches', JSNT 27.1 (2004): 2746.

37 Among other scholars who have written on the confusion resulting from mixing the house with a place of worship are: Margaret Y. MacDonald, Early Christian Women and Pagan Opinion: The Power of the Hysterical Woman (Cambridge: Cambridge University Press, 1996): 30-41, and Antoinette Clark Wire, The Corinthian Women Prophets: A Reconstruction through Paul's Rhetoric (Minneapolis: Fortress, 1990): 183. Jürgen Becker, Paul: Apostle to the Gentiles (Louisville: John Knox, 1993): 251- 
church meetings were in some sense public gatherings which assembled in private space (italics his) ${ }^{38}$ Barton then brings us to the core issue: 'Here again, Paul wants to distinguish ekklesia from oikos. The Corinthians, on the other hand, seem intent on collapsing the two spheres together. ${ }^{39}$ Building upon Barton's observation, J. D. G. Dunn offers a similar construction of events: 'Could she behave in church as she did in the privacy of the home, where she could exercise a certain amount of authority over other members of the household? Or alternatively, once home had become church, was she in effect in a new (Christian) family structure, with old structures of authority relativized?' ${ }^{40}$ Finally, I note a similar conclusion by Craig Keener who

55 , also sees the house church as the cause for misunderstanding on how to behave but does not make a connection with the women laying aside their veils. For a summary of the research, see Margaret MacDonald and Halvor Moxnes, 'Domestic Space and Families in Early Christianity', JSNT 27.1 (2004): 3-6.

38 S. C. Barton, 'Paul's Sense of Space: An Anthropological Approach to Community Formation in Corinth', NTS 32 (1986): 225-46, esp. 232. For connections between the church and other voluntary associations in the Roman Empire, see Wayne O. McCready, 'Ekklessia and Voluntary Associations' in Voluntary Associations in the Graeco-Roman World, ed. J. S. Kloppenborg and S. G. Wilson (New York: Routledge, 1996): 59-74. For a variation of Barton's thesis, see Jorunn Økland, Women in Their Place, 140. For a comparison between voluntary associations and public statutes in classical Athens, see Ilias Arnaoutoglou, 'Between koinon and idion: Legal and Social Dimensions of Religious Associations in Ancient Athens' in Kosmos: Essays in Order, Conflict and Community in Classical Athens, ed. P. Cartledge, P. Millett, and S. von Reden (Cambridge: Cambridge University Press, 1998): 68-83, esp. 72. For the argument that the early church made use of traditional household management practice (as opposed to revolutionary egalitarian status for its members), see J. H. Elliott, 'The Jesus Movement Was Not Egalitarian but Family-Oriented', BibInt 11.2 (2003): 173210. For a recent survey of possible voluntary association practice impacting the Corinthian church, see Rachel McRae, 'Eating with Honor: The Corinthian Lord's Supper in Light of Voluntary Association Meal Practices', JBL 130.1 (2011): 165-81.

39 Barton, 'Paul's Sense of Space', 234. Carolyn Osiek and Margaret Y. MacDonald, A Woman's Place: House Churches in Earliest Christianity (Minneapolis: Fortress, 2006): 4, n. 9, in their collaborative work acknowledge indebtedness to Barton at the end of a reinforcing observation: 'There has sometimes been an assumption that the house church, because it most often met in a domestic structure, also met under the rules of the private sphere, in which women are thought to have had greater freedom within the circle of the immediate family. But most often a house church meeting was not that of the immediate family, and this notion of "private rules" for it has been ably challenged by an analysis of Paul's expectations in 1 Corinthians.' For the importance Greeks attached to the inner privacy of the home, see Michael Jameson, 'Private Space and the Greek City' in The Greek City: From Homer to Alexander, ed. O. Murray and S. Price (Oxford: Clarendon, 1990): 171-95, esp. 195, his concluding sentence: 'On a small scale, the private house shows the democratization of aristocratic values, which was in so many ways characteristic of the city-state'.

40 J. D. G. Dunn, The Theology of Paul the Apostle (Grand Rapids: Eerdmans, 1998): 592. 
in his commentary on Corinthians states: 'In public, even well-to-do Roman women probably pulled a mantle over their heads; but if the church met in homes, the need for such behaviour may not have been evident' ${ }^{41}$ Mark Finney, also writing of the possible implication of the family relationship in the Roman context, has recently described the liturgical setting as it likely occurred in a domestic setting: 'Conversely, the wife may well have remained uncovered amongst kin within the home during times of domestic worship, wearing a veil only if there were outsiders (i.e. non-kin) present' ${ }^{42}$

I agree with the above statements indicating that, indeed, house church issues are a dynamic at work in the Corinthian congregation. My purpose will be to further advance the implications of this housechurch thesis. I will argue that by virtue of the Corinthian women's transformation of a public gathering of believers into a worship experience more suitable for private living quarters, their own private behaviour, normally reserved specifically for the home, has entered into public space. Consequently, the women now view themselves in the safe environment of a familiar house which is being used for public worship.

A text from the Roman Cornelius Nepos testifies to potential Greek anxieties. In his Praefatio (6-7) he contrasts the Roman custom with the Greek. He mentions that married Greek women do not attend 'dinner-parties' (convivium), 'unless relatives are present' (nisi propinquorum); 'she sits only in the interior part of the house' (neque sedet nisi in interiore parte aedium), 'in which no one has access except for relatives' (quo nemo accedit nisi propinqua cognatione coniunctus). If we accept this description as a relatively safe generalisation (to which exceptions are likely), we are given a social context for understanding Corinthian misunderstandings. Nepos mentions twice the off-limits security of a typical Greek home. The only people allowed to see the lady of the house are relatives. Dinnerparties are excluded, nisi ('unless') relatives are present. Guests are not admitted to inner quarters, nisi ('unless' or 'except') a relative. Obviously, the lady of a typical Greek family will not come out of the interior of the house unless it is to receive relatives. If we transfer this

41 Craig S. Keener, 1-2 Corinthians (Cambridge: Cambridge University Press, 2005): 92.

42 Mark Finney, 'Honour, Head-coverings and Headship: 1 Corinthians 11.2-16 in its Social Context', JSNT 33.1 (2010): 31-58. 
cultural model to the church at Corinth, a dynamic presents itself which could possibly confuse married women in the assembly. The church, in a married woman's mind, has become her extended family. In other words, since these women are now among relatives of a kind, the women may have felt safe enough in the environment to remove their veils. The men, on the contrary, do not have the same sense of security. The answer is for the women to wear their veils and to refrain from talking; the obligation placed upon the men is to stop judging.

\section{The Significance of Talking}

Another text that reinforces the thesis of this study is that of 14:35: $\varepsilon \dot{i}$

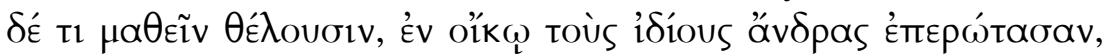

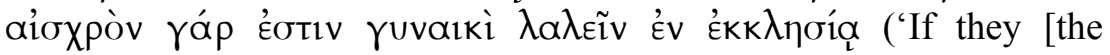
women] wish to learn anything, let them ask their own husbands at home. It is a shame for a woman to speak in church.') This is the second reference to aioxpóv. The first reference occurs at 1 Corinthians 11:6. The first reference appears vis-à-vis a married woman appearing at worship without a head covering. The second connects to a context involving talking. Therefore, the two contexts are connected by virtue of similar concerns regarding shame.

Although the verb $\lambda \alpha \lambda \varepsilon \tilde{\imath} v$ in 1 Corinthians 14 is used primarily to describe speaking in tongues, ${ }^{43}$ at vv.34-35 this verb must be understood in the sense of talking or conversing. Or, to be more specific, the context suggests that this talking is confined to asking questions. Paul's response is to enjoin the women to 'ask their husbands at home'. This text presents us again with the dynamic of believers confusing the protocol for private behaviour with those of public and allowing the private to spill out into public quarters. The hypothesis of this study continues: some Corinthian women are engaging in behaviour at church which is normally confined to the home. ${ }^{44}$ This social intrusion is not acceptable and requires a response.

Greek males perceive in a woman's voice the power to entice. This seductive quality then forms the basis of male suspicion and the

43 The verb $\lambda \alpha \lambda \varepsilon \tilde{i} v$ is used fifteen times prior to v. 34 to describe speaking in tongues.

44 See Terence Paige, 'Social Matrix', 241, who correctly considers the possibility of boundary confusion: 'Of course, this is not to say that it was the Corinthian women's intention to solicit romantic attention from other men. Their behavior could have been given impetus by the boundary confusion noted already.' 
tangential coloration of shame. Euripides in his play Electra says at

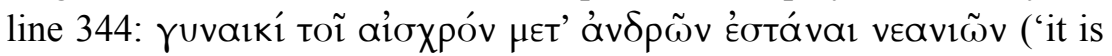
a disgrace for a woman to stand [and talk with] a young man'). ${ }^{45}$ Moving forward to the Roman period, Plutarch clearly indicates that it was talking with Cleopatra that ensnared Anthony. In his Life of Anthony (25:1) Plutarch begins to describe the manner in which

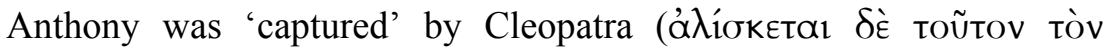
тро́тоv). There is, to be sure, her physical beauty $(25: 3 ; 27: 1)$, but Plutarch pays special attention to her o $\mu 1 \lambda \lambda^{\prime} \alpha$ or her conversation. He mentions four qualities of her voice (27:2): áquktov ('irresistible'),

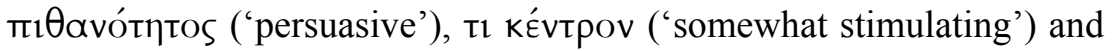

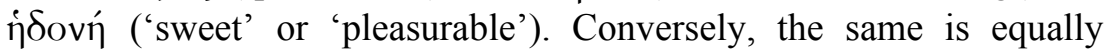
true - if not more so for a woman: when a married woman talks with a man not her husband she generates suspicions of adultery.

In his comparison between Lycurgus and Numa (3:5) in their respective treatment of women, Plutarch must defer to the Roman Numa as being wiser. Numa is considered superior in wisdom for respecting ancient tradition in that he taught the women regarding 'great modesty' ( $\propto \grave{i} \delta \tilde{\omega} \delta \grave{\varepsilon}$ по $\lambda \lambda \hat{\eta} v)$. This instruction in modesty took the form of admonishing the women in not 'meddling'

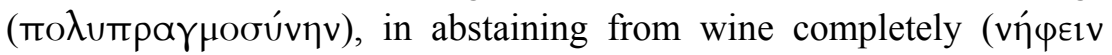

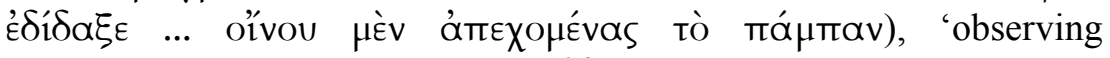

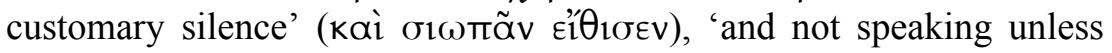

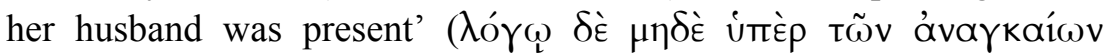

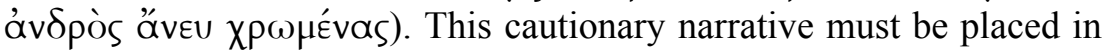
its rightful context: it is best understood as having to do with modesty while out in the public, not harmony in the home. This can be seen from the contrast with which he begins his narrative with a $\mu \varepsilon^{\prime} v \ldots$... construction. Earlier, Spartan women took great liberties when out in

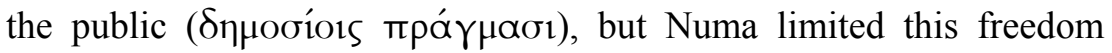
with the above proscriptions. Women were allowed to speak publicly only when their husbands were present-surely a protective measure to safeguard the marriage relationship. However, this talk has definite limitations. Plutarch uses the common NT word $\lambda$ óyos to describe her speech. This word is a derivative or cognate of $\lambda \alpha \lambda \varepsilon \tilde{i} v$ which is used at 1 Corinthians 14:35. This kind of speech which 1 Corinthians 14:35

45 See also, Euripides, Iphigenia at Aulis, 830: 'It is disgraceful for me to be speaking

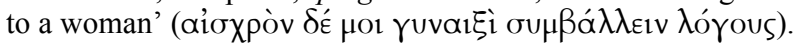


discourages for a married woman is not to be equated with prayer or prophecy as permitted in 1 Corinthians 11:5. This information, however, does involve a conflict in cultural sensitivities. Numa's prohibition - at least as understood and transmitted by Plutarchcontains a concession: a married woman is not allowed to speak in public unless her husband is present. At Corinth, however, the presence of a husband seems a safe assumption. How do we resolve this discrepancy? It is possible that the boundary line laid down by Paul is precautionary, possibly based upon the particular situation and the desire to avoid giving offence. A further comment upon this text regarding the injunctions by Numa is the reference to drinking wine. It is clear that some writers, Plutarch included, view the drinking of any wine for a woman to be a violation of modesty. So, while Paul's prohibition against talking is similar to Plutarch's, participation in the cup would be more relaxed. Although we do not have a perfect match, this comparison does suggest corresponding concerns. Plutarch provides this additional insight into how a married man might view a woman's voice:

Her speech as well, ought not to be for the public, and she ought to be modest and guarded against saying anything in the hearing of outsiders, since it is an exposure of herself, for in her talk can be seen her feelings, character and disposition. For a wife ought to do her

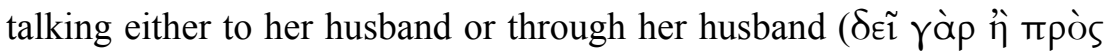

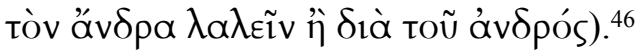

Once again, this language mirrors the language and thought of

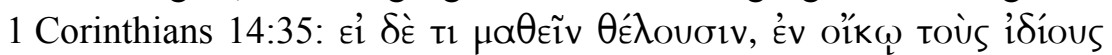

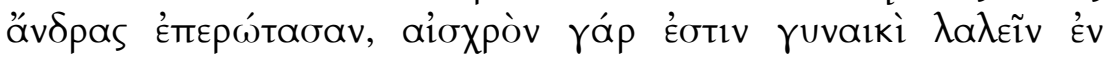
ÉKK $\lambda$ пoía ("if they [the women] want to learn/inquire about something, they should ask their own husbands at home, for it is a shame for

46 Plutarch, Conjugalia praecepta 142D. Plutarch concludes his thought by comparing a wife to a flute player. That is, a woman does not have her own voice, but rather is heard through her husband, just as a player's voice is heard through the flute. So, in a sense then, the husband is the instrument through which a wife communicates with the outside world. This, however, is only in a limited manner-for her feelings

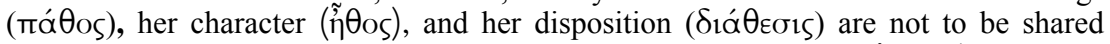

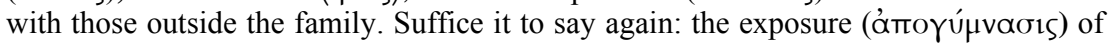
a wife's inner self is an affront to many Greek men and would probably constitute a violation of the intimacy of their marriage. For the classical view that a wife should

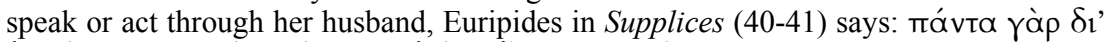

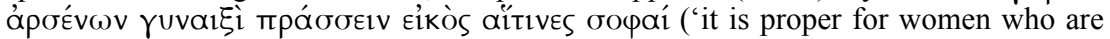
wise to do everything through their husbands'). 
woman to speak in the church'). If we combine these texts together, it is clear that a woman's voice was believed to have both sexually appealing and sexually revealing qualities to it. Furthermore, this nexus of texts indicates that what was appropriate for the privacy of one's home has intruded into the public space of a church assembly. It is not the frenzied cries of the Dionysiac cult that are being heard but, rather, the calmer (yet still troublesome) expression of a married woman's voice asking a question. This is not a case of the blurring of the sexes but a blurring of spheres and spaces.

\section{Conclusion}

I take the texts mentioned above as reflective of the social issue behind 1 Corinthians 11:2-16. A married woman's freedom to go without a veil within the safety and comfort of her own home and the equal liberty to converse at home with her husband has now entered into the public domain of a church service. The women, feeling that the church is their extended family, have taken the liberty to act as if they are at home. ${ }^{47}$ In fact, from their own point of view, the women may have actually felt very at home. If the church rotated its meetings or in some way shared responsibility for hosting a meeting, these women may have been alternately in their own homes. It is not likely that the church in Corinth met in larger quarters than a private house. ${ }^{48}$ Roger W. Gehring suggests, based upon the the most recent archaeological evidence, that the best options for a church assembly in Corinth are: the

47 Jason David Beduhn, “"Because of the Angels": Unveiling Paul's Anthropology in 1 Corinthians 11', JBL 118 (1999): 295-320, argues: 'the issue is not particular cultic prescriptions for putting on a veil in worship, but rather circumstances within worship that, for one reason or another, prompt women to take off the head covering they usually wear in public (297)'. This, indeed, is the likely situation. My argument takes the issue one step further: these women find themselves in the comfort and familiarity of a house church which enables them to think (or question "if") it is permissible to remove their veils. Clement of Alexander, Paedagogi 3.45 (PG 8), instructs women to

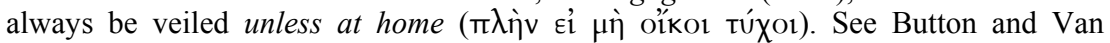
Rensburg, 'The "House Churches" in Corinth', NeoT 37.1 (2003): 1-28, for their view that Corinthian believers are actually at home-in 'home-based gatherings'.

48 For the argument that the church at Corinth may have met in a public theatre, see David Horrell, 'Domestic Space and Christian Meetings at Corinth: Imagining New Contexts and the Buildings East of the Theatre', NTS 50 (2004): 349-69. Horrell is responding to Jerome Murphy-O'Connor's monograph, St. Paul's Church,, 178-85. Unfortunately, we have no textual evidence for such larger meetings as Horrell would have us imagine. 
Roman atrium house or villa, a multi-story rental building, a Greek peristyle house, and a Hellenistic hybrid house with a courtyard. None of these options would accommodate more than ninety people. ${ }^{49}$ Therefore, we are proposing that they may have acted domestically according to the habits of their home. But this freedom creates an indecency unbecoming for such an occasion. Behaving inappropriately to the occasion is part of the background to 1 Corinthians $11-14 .{ }^{50}$

49 Gehring, House Church and Mission, 140.

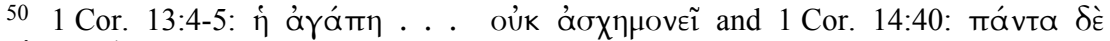

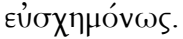

